\title{
Field trials excluded from UK crop appraisal
}

David Adam, London

Britain's field-scale trials of genetically modified crops cost millions to set up and are the most extensive studies of their kind in the world. So plant scientists were surprised to learn last week that their results will not be included in a comprehensive, government-funded science review of the safety of such crops.

The review is one of three initiatives the government has scheduled for the run-up to its decision on whether to allow the commercial planting of transgenic crops. The other two are a study of the economic benefits and a national public debate (see Nature 419, $327 ; 2002)$. The government wants the results of all three initiatives by June next year, a month before the first results from the field-scale trials are due to be published.

The trials will assess the effect on wildlife of large-scale cultivation of the crops (see Nature 412, 760-763; 2001). "These field releases are the only large-scale risk assessment that's been carried out in Britain and it's odd that we're not going to discuss them at all," says Carlo Leifert, a nutritionist who directs the Tesco Centre for Organic Agriculture in Stocksfield, Northumberland, and is a member of the panel that will conduct the science review. "It's one of the things I intend to raise at our first meeting."

Government officials say that the trials were not being included in the review because they are only addressing a narrow question about one type of crop and bio-

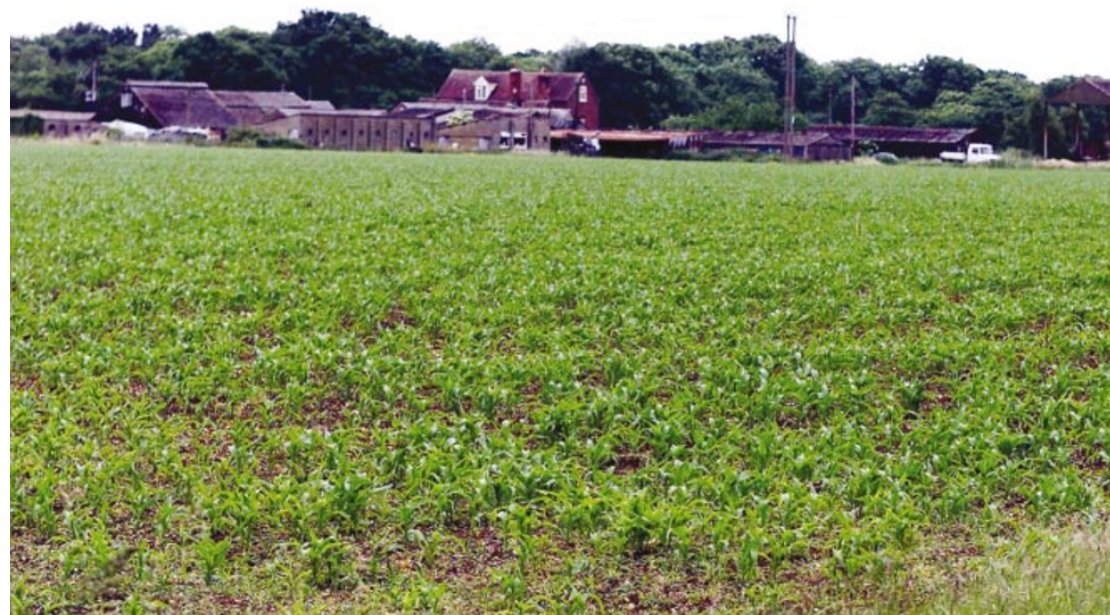

Big study, small result: government officials say that field-scale trials address only narrow questions.

diversity. "It would be absurd if we focused on one trial in the United Kingdom," says David King, the government's chief scientific adviser. "I don't think many countries know about our little experiments."

But such language contrasts sharply with previous government statements. In March 2000, environment minister Michael Meacher said: "There will be no commercial growing until we are satisfied there will be no unacceptable effects on the environment. That is why we have led the world by setting up this research programme, which will give us the answers to these important questions."
The government says that it will still consider the results of the trials before making a decision on whether to allow commercial use of transgenic crops, but many still do not understand why the results are to be omitted from the science review.

Researchers advising the government could only say that they have come under pressure to ensure that the review and debate are finished before the trials' results come out. "They were very clear that they wanted it over and done with by June," says one member of the steering group that will coordinate the public debate.

\section{Royal Institution's director blasts scientific sexism}

\section{David Adam, London}

Pity Danielle Ohayon, otherwise known as Miss Jamaica, a contestant in this year's Miss World competition. Already forced to relocate to London following violent protests against the beauty pageant in Nigeria, Ohayon received further bad news last week - she faces institutional sexism if she follows her desired career in marine biology.

Likewise, if Mai Phuong Pham Thi Miss Vietnam - lives out her dream and becomes a physicist, she may find it difficult to return to work if she wants to take a break to have children. And Chinenye Ochuba - Miss Nigeria - is likely to strike the long-standing and notorious glass ceiling should she achieve her ambitions in computer science.

The gloomy prognosis of young women's prospects in science arrived in a report from Susan Greenfield, director of the London-based Royal Institution of Great

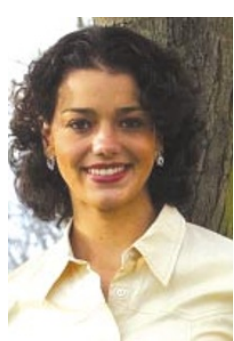

Britain. Commissioned by the British government and published on 28 November, the report calls for state funding for fellowship schemes to retrain women who have taken breaks in their career to start Miss vocation: aspiring biologist Danielle Ohayon. a family.

It also calls for funds for familyfriendly practices such as part-time working and job-share programmes, which it says would help women to rise through the research ranks.

"Thankfully we have gone beyond bottom pinching, but in some ways the latest form of discrimination is worse," Greenfield says. "It's hidden, institutional sexism, clearly reflected in the awful statistics." Just $8 \%$ of women academics in Britain's older universities are professors, for example, and more than a third are on the lowest lecturer pay scale. The report points out that there are similar problems in other countries, echoing accounts that sexism persists in the United States, Japan and elsewhere.

The low participation of women in British science is not just a problem for them, the report says, but also for the country, business and society as a whole.

It adds that many of the efforts and initiatives to encourage greater participation are fragmented - and that many women in science are unaware that they even exist. To address this problem, the report suggests that the government should set up a 'working science centre' to draw these programmes and schemes together. The government says that it intends to consider the recommendations and will publish a full response shortly. 